\title{
The Evolution of the Female from Suppression to Supremacy in the Select Novels of Postmodern Retellings of the Epic- A Review of Literature
}

\author{
Parinitha B. ${ }^{1} \&$ A. Lourdusamy ${ }^{2}$ \\ ${ }^{1}$ Research Scholar, College of Social Sciences \& Humanities, Srinivas University, \\ Mangalore, India. \\ Orcid ID: 000000033589 6305; Email: parinithabravi@gmail.com \\ ${ }^{2}$ Research Professor, College of Social Science \& Humanities, Srinivas University, \\ Mangalore, India. \\ Orcid ID: 000000029011 6212; Email: swamysac@ gmail.com
}

Area/Section: English Literature.

Type of the Paper: Exploratory research paper.

Type of Review: Peer Reviewed as per $|\mathrm{C}| \mathrm{O}|\mathrm{P}| \mathrm{E} \mid$ guidance.

Indexed in: OpenAIRE.

DOI: https://doi.org/10.5281/zenodo.6302482

Google Scholar Citation: IJMTS

\section{How to Cite this Paper:}

Parinitha, B., \& Lourdusamy, A., (2022). The Evolution of the Female from Suppression to Supremacy in the Select Novels of Postmodern Retellings of the Epic- A Review of Literature. International Journal of Management, Technology, and Social Sciences (IJMTS), 7(1), 163-183. DOI: https://doi.org/10.5281/zenodo.6302482

International Journal of Management, Technology, and Social Sciences (IJMTS)

A Refereed International Journal of Srinivas University, India.

CrossRef DOI: https://doi.org/10.47992/IJMTS.2581.6012.0184

(C) With Author.

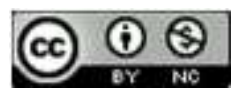

This work is licensed under a Creative Commons Attribution-Non-Commercial 4.0 International License subject to proper citation to the publication source of the work.

Disclaimer: The scholarly papers as reviewed and published by the Srinivas Publications (S.P.), India are the views and opinions of their respective authors and are not the views or opinions of the SP. The SP disclaims of any harm or loss caused due to the published content to any party. 


\title{
The Evolution of the Female from Suppression to Supremacy in the Select Novels of Postmodern Retellings of the Epic- A Review of Literature
}

\author{
Parinitha B. ${ }^{1} \&$ A. Lourdusamy ${ }^{2}$ \\ ${ }^{1}$ Research Scholar, College of Social Sciences \& Humanities, Srinivas University, \\ Mangalore, India. \\ Orcid ID: 000000033589 6305; Email: parinithabravi@gmail.com \\ ${ }^{2}$ Research Professor, College of Social Science \& Humanities, Srinivas University, \\ Mangalore, India. \\ Orcid ID: 000000029011 6212; Email: swamysac@ gmail.com
}

\begin{abstract}
Purpose: Man, in contrast to other creatures, is concerned with spiritual issues such as cognitive, social, artistic, and political concerns. A deep relationship has existed between faith and humanity since the dawn of time, if not before. The various religious and cultural beliefs are reflected in myths. As a result, the history of civilizations is primarily linked to and identified with mythology and religion. With the guidance of mythology and culture, people can better understand their world and the meaning of life. Thousands of years had passed since the epic narratives were penned. However, the astonishing stories continue to uncover conspicuousness in every genre of art and continue to engulf and overwhelm us even today. Epic narratives are still loved not only for their poetic grandeur but also for the highest philosophical principles they contain, which educate us about the art of living. As a result, the Mahabharata is one of the most important writings in Indian culture, and its stories, which practically everyone has grown up hearing, are still relevant today. It is a true embodiment of a useful scripture that offers the modern man with a traditional, moral, and liturgical grounding even in the contemporary society. It is not just a story of morality to be narrated from the generations, but an unending source of study. Plenty of critics have studied the text from many perspectives, still much remains to be discovered and researched. The study intends to read four new retellings of the Mahabharata novels and look afresh into the four powerful female characters, namely, Sathyavati, Gandhari, Kunti, and Draupadi. The study discovers the quest for self-crisis of the four prominent female characters by applying feministic study, power politics, and gender views. The study mainly focuses on the comparison and contrast between the concept of western and Indian feminism.
\end{abstract}

Methodology/Approach: The Literature Review is carried out by the information collected from different sources like educational websites, peer-reviewed journals, and online sources. The proposed research will be carried out relying on the data collected through research journals, doctoral thesis, scholarly articles, and websites. This qualitative approach is conducted mainly based on collecting, examining, and interpreting existing knowledge on the selected topic by focusing on the keywords "Feminism, Prominence, Relevance, Retelling, SelfCrisis, and Western". The methodology of the study is the textual analysis and comparative method.

Findings/Result: Vast reading of mythology will enhance the further areas of study. The gap between western feminism and Indian feminism helps to identify the discrimination of women in a clear way. The detailed study of the construction of gender views over the years makes it insightful about the issue. Discover that there is a connection between feminist studies with other theoretical frameworks. Modern retellings of the epic novels widen the scope and understanding of the original work. The scope and relevance of feminism in India are become more clear by comparing and contrasting the Indian and western concepts of feminism. 
Paper type: Exploratory research paper.

Keywords: Feminism, Prominence, Relevance, Retelling, Self-crisis, Western.

\section{INTRODUCTION :}

Man is a meaning-seeking creature at the core of his being. Culture and mythology have arisen since the beginnings of history, thanks to the strength of human imagination and reasoning. As a result, the mythology and culture of a particular country serve as the foundation for many accomplishments of mankind. The nation's cultural identity is defined by mythology, which plays an important role in this. When it comes to a man's ultimate worry, the elements of confidence are his most important assets. Man, in contrast to other creatures, is concerned with spiritual issues such as cognitive, social, artistic, and political concerns. The creation of myths is a reflection of the various religious beliefs held by people. In this way, the historical background of civic institutions are connected to and is primarily connected to, mythology and religion. People use mythology and culture to help them understand their world and the meaning of life [1]. Without myths, the human world would be inconceivable. We would have been completely lost if it weren't for mythology. Myths have been passed down from generation to generation, preserving the cultural heritage of the people. It is the legends, folktales, fables, and myths that constitute the collective consciousness of a country. This means that the historical backdrop of civilizations is connected to and intimately connected to their stories. The cultural identity of any country is intertwined with its extensive collection of mythological stories. As a result, mythology may be found in all civilizations of the human species.

The Ramayana and the Mahabharata are the basis of Indian culture. The epic story of the Mahabharata had been composed millennia prior. However, the incredible story keeps on discovering conspicuousness in each type of craftsmanship and keeps on overpowering us even today. The way that the epic is as yet adored isn't simply because of its graceful magnificence however the profoundly philosophical thoughts that propagate all through the epic have a great deal to show us the craft of living. It is quite possibly the main messages of Indian culture and its accounts that practically we all have grown up with hold pertinence in any event, during present occasions. The Mahabharata isn't only an account of profound quality to be described from the ages, however a ceaseless wellspring of study. A lot of critics have been considered the text from various perspectives, still, a lot of still needs to be found and explored. Though the Mahabharata belongs to a remote past but embedded its relevance even to the present in a creative manner as Eliot says presentness of the past and pastness of the present [2]. The conflict between the dharmas is the root cause to write the Mahabharata. The source text of Mahabharata of Vyasa portrayed profoundly the economic, political, social, and religious conditions in the Vedic culture. However, Mahabharata has its origin in the distant past, yet its importance can be applied to the present period. For many centuries, generations of authors have produced the huge work called Mahabharata. It is not just a story of enmity between two family clans and their power struggle, but a didactic, spiritual and philosophical fountain. In terms of length, the Mahabharata holds the distinction of being the longest epic in world literature, but it is more than just an epic, as it is a romance, telling the story of heroic men and women, including some who were divine; it is complete literature in and of itself, containing a code of life, a philosophy of social and ethical relations, and speculative thought on human problems [3].

Men make the rules in patriarchal societies, and generally women follow them. The position of women in society has shifted over time. These developments took place at different times throughout history. Women in India have had to deal with many ups and downs throughout history. She has confronted every crisis with courage and dignity since the Vedic era. Women have long been regarded as the personification of Shakthi in our mythology. Women in the Mahabharata not only oppose men's actions but also play a vital part in a variety of scenarios. As a result, we cannot argue that the Mahabharata's women are wholly subordinate or submissive, or that they lack their own identity. The Mahabharata's women were powerless and helpless in certain situations, but they were not weak. They carried out their roles as mother, wife, and daughter following societal expectations. They were bold and powerful enough to confront life's obstacles because of their ambition, intelligence, and inner strength. The study aims to explore the boldness and heroism of the four significant women characters of the epic Mahabharata. The examination expects to peruse four new retellings of the Mahabharata novels and look anew into the four amazing female characters, in particular, Sathyavati, Gandhari, Kunti, and 
Draupadi. The study aims to discover the quest for self-crisis of the prominent four female characters by applying feministic viewpoint, cultural discrimination, power politics, and gender viewpoint.

\section{BOOKS SELECTED FOR THE STUDY :}

Table 1 projects the books which are selected for the research work. All four retellings of the epic are the latest and exhibit unique narration.

Table 1: Books selected for the study

\begin{tabular}{|l|l|l|}
\hline \multicolumn{1}{|c|}{ Name of the Book } & Publishing Year & \multicolumn{1}{c|}{ Author of the Book } \\
\hline The Kaunteyas & 2016 & Mahadevi s Mahadevan \\
\hline The Fisher Queen's Dynasty & 2017 & Kavita Kane \\
\hline The Palace of Illusions & 2018 & Chitra Banerjee Divakaruni \\
\hline The Curse of Gandhari & 2019 & Aditi Banerjee \\
\hline
\end{tabular}

Source: Compiled by the researcher.

\section{OBJECTIVES :}

The following are the objectives of the study.

(1) To comprehend the rich heritage of the mythology and its relevance in the present scenario.

(2) To know the difference between the concept of western feminism and Indian feminism.

(3) Understanding the scope and changes of gender perspective over the years.

(4) Analyze socio-historical, myth-cultural gender dynamics and contemporary sexual politics.

(5) By combining both Western and Indian feminism, try to find out a new perspective that is suitable to Indian ethnicity.

\section{SIGNIFICANCE OF MYTHOLOGY :}

Several valuable parts of mythology have been incorporated into Indian culture, which has helped to elevate it even more and distinguish it as a truly distinct cultural expression throughout history. The transmission of numerous stories from one generation to another in Indian Mythology has occurred over the centuries, either by listening in on others discussions or by preserving sacred documents that have been carefully preserved. Because it is the foundation of Indian culture, it serves as an excellent vehicle for instilling ideals and respect for our heritage in future generations. Indian mythological narratives intend to transmit subtle facts, principles, and laws that can be used to assist us in our daily life [4]. Throughout history legendary tales have been transmitted from generation to generation to inform, educate, and entertain the audience.

The epics demonstrate what is the proper way to live and lead one's life. It clarifies the true meaning of life. Epics are built on long-standing traditions that recount the heroic figure's exploits. We have two great epics in India. Both the Ramayana and the Mahabharata, written by Valmiki and Vedavyasa, were initially written in Sanskrit. Lord Ram was exiled for 14 years with his wife Sita and younger brother Laxman, according to the Ramayana. It highlights a number of fundamental primary values that are instilled in every child. The Mahabharata is the longest epic, which throws upon the politics played and teaches us to pursue the duties assigned to us. They teach us how to become good human beings and the actual importance of relationships in life [5]. If we study Indian mythology we find many events, activities, monuments prove that without principles of management this would have not taken place.

\section{AN OVERVIEW OF LITERATURE :}

The Palace of Illusions by Chitra Banerjee Divakaruni is an insightful retelling of the timeless epic. Divakaruni writes about women, challenges faced by immigrants, history, myth, family, and hardships of living in a multicultural world. Her novel The Palace of Illusion is a deeply moving retelling of the great timeless epic Mahabharata from the Draupadi's point of view. We all came across the tale of the epic in our life which is the perspective of men. Here the author gives us a glimpse into the life of Panchali, a woman who faces challenges right from her birth. It tells us about her relationship with her 
twin brother, her best friend Lord Krishna, her bond with Pandavas, and their mother Kunti [6]. It explains the role played by women in a world dominated by men. It beautifully exposes the different situations in which she had to choose between the heart and mind. Even though the women played a significant role in the epic, they were depicted as the supporting characters subservient to their male counterparts. It encourages women to stand headstrong to all the challenges, without being dependent on anyone.

Vipula Gupta's review of The Palace of Illusion emphasizes that Divakaruni does not modify the plot or present another ending, but rather she offers a fresh new viewpoint on the story. The narrative begins with her birth in King Dhrupad's palace and swings between flashbacks and the present, unearthing events from the past and fleshing out the characters as they are introduced. Banerjee's princess is a young rebel, a tomboy who yearns for her father's approval and who is desperate to make her mark on the world around her. The princess who was born out of the fire is crowned queen, and she proceeds to construct the palace of illusions, the most gorgeous abode on earth constructed of marble and magic [7]. It is determined that the history will be changed by her, and she becomes queen. Seen in the context of her spiritual faults, hubris, and a desire for retribution, her worldly successes are a mixed bag. There is one constant in her life throughout the narrative, and that is the beneficent presence of Krishna, her dearest friend. As a result, the novel offers an intimate female portrait that is both modern and eternal in its perspective [8]. Divakaruni deconstructs the stereotype of myths that are dominated by males into myths that are dominated by women. It is the writing in the genres of epic fantasy and mythological fiction that has a feminine narrative, and the book is one among these genres.

Aditi Banerjee's portrayal of Gandhari in The Curse of Gandhari is both creative and compassionate, and Gandhari is a compelling character. Aditi Banarjee saves her from being relegated to a simple symbol of her blindfold by rescuing her from that fate. She portrays her as an unorthodox heroine with immense power and iron will, who embarks on a complicated relationship with Lord Krishna and eventually becomes the queen who cursed even a god, among other things [9]. The novel depicts the story of a fiercely clever princess who purposely blindfolded herself for the sake of her peevish, visually challenged husband to save his face. A difficult pregnancy led to her becoming the mother of one hundred sons, all of whom were worthless, and her harsh meditation did not earn her a place in the hearts of anyone who knew her. In modern times, she is regarded as either an ingratiatingly selfsacrificing wife or a horrible mother who was unable to control her sons and was thus held accountable for the Great War and the disintegration of the family unit. When Gandhari took the vows to blindfold herself, there was no acknowledgment for her actions, in contrast to Bhishma's, who was called Devavruta after his vows. It was taken for granted because, in our society, women's sacrifice is considered normal. However, this novel reveals a previously unseen side of her, as well as providing new insight into the topic of gender discrimination. It is through this lens that the blindfolded queen, the mother of villains, is developed as an unorthodox heroine with tremendous strength and willpower. She was a loving mother, a devout wife, and a strong queen who worked tirelessly to ensure that her sons followed the correct path, but her love for them surpassed everything else. That makes us consider her life's experiences. She admonished her sons over and over again to pursue the path of dharma and make peace with the Pandavas [10]. This demonstrates her tenacity of character.

In 'Decoding Gandhari, the Queen of Iron Will'book review by Sravasti Datta says that Aditi Banarjee, in her The Curse of Gandhari, goes beyond the surface story of Gandhari blindfolding herself as an act of devotion to her husband and delves deeper into as a princess and mother who is not meek or submissive [11]. The magnificent vigor and determination of her dared to curse Krishna and Yudhishthira's toenails burnt because of her deep sorrow, anger, and dissatisfaction. Even though she is noble and rich in character, she had to be in unfortunate circumstances. Aditi explains her blindfolding in a new enigma and perspective that as an act of resistance or rebellion for who dominated her. The more explanation is that she is very downhearted not to succeed the throne so that she blindfolds herself as an act of torment. In the novel, in Satyavati's opinion that while the men win wars and conquer kingdoms and win name and fame and honor, it is we women who maintain the kingdom unharmed. It reminds the word the hand that rocks the cradle does rule the world because while men make empires, women make the men who create the empire [12]. Even though men fight and win wars, it is women who make victory possible. By blindfolding herself the queen withdraws herself from everything, hides from everybody, and in this way, she subsides some other facts which are cruel but heart-rendering 
[13]. Here in this novel, Gandhari finds herself as the dame of the Kuru dynasty after Satyavati left but full of dilemmas and deficiencies. Gandhari certainly succeeded as a woman and a woman who was love and reach the highest peak, even though failed as a wife and mother.

In Kavita Kane's novel, The Fisher Queen's Dynasty, Satyavati, the queen of Hastinapur, who was abandoned as a newborn and preyed on by a rishi, hardens herself and resolves that the next time she is with a man; she will be the one to win. And win she does, claiming the kingdom of Hastinapur for herself and her sons, but at an incalculable cost to herself and her children [14]. She is despised and reviled in a palace, but she puts up with all of this because she has chosen to participate in the game of politics and accepts all of the consequences. The war was the culmination of an astute grand grandmother of the Kuru family's never-ending endeavors. Her development across time, through the eras, through hardships, and through challenges is vividly shown in the chapters. Her journey to womanhood was not an easy one, and her sufferings, obstacles, and difficulties caused her to become cold-hearted towards men. This story is highly interesting, enthralling, and engrossing to the point of being completely consumed by it [15]. It tells Satyavati's path from being a simple Fisherwomen to becoming the queen of Hastinapur.

The Kaunteyas by Madhavi S Mahadevi presents Kunti who forsaken in birth and had a hard but tedious life in her adopted parent's home. At the age of fourteen, she is forced to the service of the temperamental sage Durvasa, who grants her a boon [16]. Its first use out of curiosity brings her adversity and a shameful secret. She dreamt of a better future when she got married to Pandu but his curse made him forsake the throne and she followed him when he retreats towards jungle. The birth of Pandavas rekindled Kunti's expected of coming back to her hometown yet ravished when Pandu died unexpectedly. Kunti returned to the palace not as a monarch, but as a widow who had the task of upbringing her fatherless children. Her struggle became harder when her illegitimate son whom she abandoned long ago sworn enemy of her children. Recasting the timeless epic from the perspective of Kunti, it restores the apotheosize the mother figure with a fully stereoscopic lady. It also brings to light the sense of isolation that Kunti feels right from childhood, her feeling of abandonment, and her wish to find a place of her own [17]. Thus, the novel explores the feministic portrayal of Kunti as a woman destined to live boldly not to subjugate.

The novel Karna's Wife: The Outcast's Queen by Kavita Kane, reveals an interesting tale of Uruvi, the second wife of Karna which throws light more on the character of Karna. Uruvi is depicted as a strongwilled princess and the primary anchor in Karna's turbulent life. Raised by a doting father in a royal palace, Uruvi finds herself facing many challenging situations which shatter her faith [18]. But having gone against family and society she has to tolerate everything and live her choices for the sake of her child. Even though it is the story of Uruvi, Karna stands out as a prominent central character. Uruvi is a shrewd woman who will not hold herself back from questioning the wrongdoings whosoever it may concern [19]. The novel portrays the female characters Uruvi and Vrushali who are victims at the hands of men and fate and how they successfully balance and endure their lives. It is very interesting to read how these two female characters have come out of all gritty situations by facing the veracity and lived mightily.

Millennials have progressed and but the Mahabharata's exceptional enchanting potentiality endure throughout the universe. Hence it is reproduced and retold by many. If one takes any regional rendition of the great epic, one can find it in Jaya Mahabharata by Devdutt Pattanaik. The 108 chapters wonderfully reveal the captivating journey of the princes of the Kuru dynasty. Along with the original classic, it includes tales and characters from several local adaptations of the epic. The writer narrates the story simply weaving the tales with one another, building up the vivid spectra of characters. The author emphasizes the fact that, History keeps repeating itself until humans learn not to make the same mistakes again and again [20]. We are always been more worried about the spirituality. And the biggest achievement of an Indian was considered to acquire 'Jaya', a victory over himself. The Mahabharata still exerts a marvelous influence over millions of people. The luster and high renown of these brilliant personages of Mahabharata have not suffered a diminution, despite the ravages of cruel time [21]. Their character was untainted and sublime.

The thesis 'The Supremacy for Power and the Quest for Self: A Critique of Gandhari, Kunti and Draupadi in the Mahabharata' by Anupama Venugopal, proves that epic is not just a story to be told and passed on from generation to generation, but an interesting and inspirational source of study. It depicts the culture, tradition, and way of life of long-forgotten years. Indian culture is rich and diverse 
with the timeless epic tales of Ramayana and Mahabharata. They hold a place of special veneration in Indian culture and society. Thousands of years old tales inspired numberless poets, writers, and artists across the globe. Even though plenty of researchers have been conducted on the great epics, the magnitude and enormity of the texts and the insightful observations about life make it relevant even today. There is plenty of opportunities to look into more introspection and revisiting will open up new avenues of thought and expression [22]. Though innumerable studies had been conducted on the text, still much remains undisclosed and researched. Mythological representation of females is not merely a woman of flesh and blood but bold and benevolent. It has proved in the postmodern retellings of the great timeless epic the Mahabharata such as The Fisher Queen's Dynasty, The Palace of Illusion, The Curse of Gandhari and The Kaunteyas. It is important to note that the unbinding of the heroine's hair is associated with the collapse of order [23]. Draupadi has her revenge, washes her hair with the blood of her abusers.

Faith Berk contends in her article, 'The Role of Mythology as a Cultural Identity and Cultural Heritage,' that man is a meaning-seeking creature. Humanity's capacity for imagination and critical thinking allows us to assume that culture and mythology have existed since the dawn of time [24]. As a result, the mythology and culture of a particular country serve as the foundation for many of mankind's accomplishments. The nation's cultural identity is defined by mythology, which plays an important role in this. A man's ultimate concern is reflected in the dynamics of his religious belief system. Man, in contrast to other creatures, is concerned with spiritual issues such as cognitive, social, artistic, and political concerns. A deep relationship has existed between faith and humanity since the beginning of time, if not before. The creation of myths is a reflection of the various religious beliefs held by people. As a result, the history of civilizations is primarily linked to and identified with mythology and religion. With the guidance of mythology and culture, people can better understand their world and the meaning of life. Without myths, the human world would be inconceivable. The myths have been passed down from generation to generation, preserving the cultural heritage of the people. It is the legends, folktales, fables, and myths that constitute the collective consciousness of a country. As a result, we can see the relevance of myths throughout the history of the human species. Any country's cultural identity is intertwined with its extensive collection of mythological stories. As a result, mythology may be found in all civilizations of the human species.

Indian mythology is one of the richest and diverse parts of Indian culture, which further enhances it and distinguishes it as a distinct cultural entity in the world. Stories from Indian mythology have been passed down the years, either by word of mouth or by the meticulous preservation of sacred texts in sacred places. Because it is the foundation of Indian culture, it is an excellent medium through which people may instill values and respect for our culture in the future generations of the population. Simple truths, principles, and maxims are communicated through epic stories to guide us through our daily life [25]. The mythical stories are intended to be enlightening, educational, and entertaining, and they have been passed down from generation to generation for hundreds of years. The epics demonstrate to us what the proper way to conduct one's life is. It describes the true meaning of existence in its most basic form. Epics are stories that are based on established traditions and tell the story of the exploits of heroic figures. Among India's greatest works of literature are two major epics: the Ramayana authored by Valmiki and the Mahabharata produced by Vedavyasa, both of which were initially written in the Sanskrit language. The Ramayana tells the account of Lord Ram, who was exiled for 14 years with his wife Sita and younger brother Laxman, and how they overcame their ordeal. It puts to light many of the fundamental core values that are instilled in every child. The Mahabharata is the world's longest epic, and it is a lesson in how to carry out the responsibilities that have been placed on our shoulders. They instruct us on how to become a good human being as well as the true significance of interpersonal interactions in one's life.

\section{REVIEW OF LITERATURE ON THEORETICAL FRAMEWORK :}

A scholarly article in INQUIRIES Journals by Vivek K Dixon named Western Feminism in a Global Perspective', explains the female identity is different according to each culture and their customs, but almost all cultures of the world are based on a patriarchal past where men display more power than women. Women throughout the world experience conquest by others in the form of education, jobs, economic, sexuality, and reproduction [26]. All countries have vastly differing histories, myths, socioeconomic frameworks, and evolving social expectations that impact what it means to be male or female 
in each society. Thus, such issues of gender and sexuality should translate differently. American women have struggled historically against certain paradigms of inferiority that all women experience. They have strived to overcome these stereotypes and have gained a position of near equality in many societal constructions. In the United States today women can and cast their vote, own businesses, hold political office, and have a full spectrum of rights. Western culture is prevalent worldwide and imposes both positive and feminist ideas and conflicting negative media messages on third world and developing countries. American feminism has evolved strictly within the boundaries of the United States. So the concept of feminism is limited to that particular country and culture and cannot extend globally to all women whose culture is entirely different. All countries have vastly differing histories, myths, socioeconomic situations; unique cultural and political frameworks, etc are played a significant impact in the role of males and females. It varies from society to society and from culture to culture and thus these issues of sex and gender translate differently.

Rajpal Kaur's article, 'Feminism: Introduction and Aims' reveals that feminism is a way of thinking which stresses equality for men and women in all fields. It aims to provide equal opportunities for all and strictly opposes discrimination based on sex and gender. The various types of feminism may have certain common concepts but the ways to explore privilege are different. Sally J Schokz opinions Feminist methodology takes the lives of women as central. According to Krishnan Das, Feminist methodology aims to understand gender inequality and focuses on gender politics, power relations, and sexuality [27]. They explore the real cause of the inequality that exists between men and women in society. Women are generally considered biologically weak and treat as inferior to men. This disparity of power relationship exists in society which decides the status and position of men and women in society. By establishing women are weak and meek, men exercise their power over them. Discrimination, suppression, objectification, oppression, patriarchy, stereotyping are the different ways in which they are marginalized. As Simone de Beauvoir says, one is not born, but rather becomes a woman. Hence, she says that gender is socially constrained. The sole concern of the feministic study is women should not be treated as mere sexual objects and they demand to treat them as human beings. They argue that earth is a place for both man and woman.

According to Maitrayee Chaudhuri's research paper, 'Feminism in India: The Tale and its Telling,' Indian feminism arose and flourished within the material and ideological dynamics of colonialism, and that this is reflected in her work. Various factors, such as the history of colonialism and the formation of Indian nationalism, the consequences of this for independent India, the setting of globalization, India's underlying culture and tradition, and so on, all played an important role in the emergence of feministic research in India [28]. Feminism in India is a collection of movements aimed at defining, establishing, and protecting the rights and opportunities for Indian women in all areas of life, including politics, economics, and social affairs. Western feminism has, however, taken on established forms in the Indian setting, which shows that there are some other avenues to take to address the problem. With the colonial history and female affiliation with national culture, feminism has been associated with an unauthentic westernization, leading to a selective association of feminism with an authentic westernization. Separate attention should be paid to the conceptual legacies of western and Indian feminisms, which differ significantly. The difficulties associated with using analogous ideas from western contexts in Indian situations are not always appropriate. It should emphasize the misleading role that critiques are now playing in Indian feminist debates, as well as on the need for a more careful assessment of the consequences of expanding disparities on patriarchal systems, among other things.

Swati Parashar in 'Feminism and Post-colonialism' opinions that as Leela Gandhi notes that, it is the encounter with feminism that encourages postcolonialism to produce a more critical and self-reflexive account of cultural nationalism. On the other hand, postcolonialism offers feminism the conceptual toolbox to see multiple sites of oppression and reject universalisms around gendered experiences of both men and women [29]. The conflicting and contradicting claims of feminism have sometimes troubled post-colonialists. Feminists also collide with post-colonials in the case of understandings of the 'third world women' and the overruling of gender hierarchies in some places. To account for the gendered differences and the violence exercised by the postcolonial states is very difficult. Most of the voices remain unheard in the post-colonial states that they experience multiple forms of violence. In many cases, women are oppressed and forced to accept the ways of the post-colonial states. The national 
identity of any nation is reflected in its gendered impositions on women. That is why the feministic viewpoint cautiously argued for social equality.

Postmodernism and Feminist Politics, by Sasha Roseneil, demonstrates how the feminist study has maintained its position as a component or offshoot of postmodernism. An understanding of the orderly world of the feminist theory lies more appropriately in the territory of postmodern philosophy than it does in feminist theory. Feminism, by any definition, is a social and political force that seeks to alter the existing power relationships between men and women in society. As an object of both analysis and development of knowledge and its representations, the feministic study has been chosen as a starting point. It has also been concerned with the challenge to develop a platform through which information can be communicated to the public. As a result of all of this, place feminism became a subset of metanarratives of modernism. As Simone de Beauvoir pointed out in 'The Second Sex,' women in western thought have represented the Other that might validate man's identity as Self, as a rational thinking person [30]. The feministic research strives to provide a theoretical explanation of oppression through social reform. That is, man has placed himself in the category of Self and has erected women as the category of the Other. Either feminism or post-modernism makes universal assertions about the existence of God, the nature of nature's powers of reason, progress, science, language, and the topic of one's own self in equal measure.

'Feminist Perspectives and International Relations', a journal article by Dr. Lianboi Vaiphei expresses, a feministic study in international relations made it more open with the construction of new knowledge. This has been done by adopting methods of de-constructivism which is associated with postmodernism, poststructuralism, and post-colonialism. Thus the feministic study can construct theories using the conceptual tools and builds the feministic framework of knowledge. The feminist study conventionally concerns of political identity and citizenship, nature of power, violence, security, and economy are addressed and brought into the gender perspective. The interconnection of feministic study with other theoretical frameworks will help in achieve political, economic, and social consideration for women [31]. The sole concern of the feminist theory is to reveal women's sufferings and seek ways to resolve them. Hence it is connected with postmodernism, postcolonialism, power politics, and gender theories. Feminist study persists in seeing itself as a component or offshoot of postmodernism.

\section{RESEARCH GAP :}

The following is the research gap in the selected topic of the study:

The Mahabharata is not only an account of profound ethical quality to be described from the ages, but a ceaseless source of study also. A lot of scholars have been examined and studied it from various points of view, still much left to be found and explored. This research intends to study four new retellings of the Mahabharata novels and look afresh into the four incredible female characters specifically, Sathyavati, Gandhari, Kunti, and Draupadi. These post-modern retellings narrate the story from the female perspectives and the studies based on these new novels have not been conducted yet. The novels selected for the study are:

1. The Kaunteyas (2016) by Madhavi S Mahadevan

2. The Fisher Queen's Dynasty(2017) by Kavita Kane

3. The Palace of Illusion (2018) by Chaitra Banajee Divakaruni.

4. The Curse of Gandhari (2019) by Aditi Banerjee

The study aims to discover the quest for self-crisis and gender identities of the prominent four female characters by applying feministic and gender viewpoints, postmodern deconstruction theory, power politics. In the modern era, it is inevitable to identify women, but in the name of assertiveness, they must not be uprooted from the base. The amalgamation of mythology, tradition, and modernity of the current world has been presented in these retellings. We Indians give more respect to our culture and epics. So, it is not preferable and acceptable to criticize it. Being feminism is an intellectual and social movement that concerns the inequality of the social structure and that itself is its limits. There is much remained to discover in the latest narratives of epic retellings in this technological era. These new retellings of the epic novels widen the scope and understanding of the original work.

\section{POSSIBLE RESEARCH AGENDA :}

The following are the possible research agenda: 
- The research intends to look afresh into the four powerful female characters of the timeless epic namely, Satyavati, Gandhari, Kunti, and Draupadi.

- To compare and contrast the concept of western feminism and Indian feminism.

- To dismantle the craze of viewing everything through the color glass of the western approach and try to discover the nativity.

- Try to de-center the primacy of the west by re-engaging with the ancient Indian ethnicity.

\section{CHAPTERIZATION OF THE RESEARCH :}

The following are the chapters of the proposed thesis:

The proposed thesis consists of five chapters. The first chapter is an introductory chapter that throws light on the significance of mythology in the modern period. People still like mythology today because it often conveys eternal and universal themes. They are related to both the art of storytelling and the performance of human experience. Myths give us an in-depth understanding of the values and perspectives of cultures long ago. These stories provide clues about how these people live and the type of society they live in. For this reason, myths show us how different human lives were when these stories appeared, and what the same remained. Mythology is a system of thoughts that shape our existential outlook on our day-to-day life.

The second chapter, titled 'Transformation of Woman,' explores the differences between the concepts of feminism in India and the West, as well as the role of women in society. Each society and its norms have its own definition of what it means to be a woman, yet practically all societies around the world are based on a patriarchal past in which men hold more power than women [32]. Worldwide, women suffer conquest by others in the areas of education, jobs, finances, sexuality, and reproduction, as well as in other areas of life. There are significant differences between countries in terms of their histories, myths, socioeconomic systems, and growing societal expectations, all of which have an impact on what it means to be a man or a woman in each society. As a result, topics of gender and sexuality should be translated uniquely. That is one of the reasons why there is such a significant gap and divergence between the western concept of feminism and the Indian concept of feminism. Feminism in India is a collection of movements aimed at defining, establishing, and protecting the rights and opportunities for Indian women in all areas of life, including politics, economics, and social affairs. Western feminism has, however, taken on established forms in the Indian setting, which shows that there are some other avenues to take to address the problem. With the colonial history and female affiliation with national culture, feminism has been associated with an unauthentic westernization, leading to a selective association of feminism with an authentic westernization. The study attempts to address some of the differences between western and Indian feminism's intellectual legacies, as well as the difficulties associated with applying identical ideas from western contexts in Indian situations. Specifically, it emphasizes the misguided role that critiques are now playing in Indian feminist debates, and it calls for a more thorough examination of the effects of expanding disparities on patriarchal systems.

The third chapter examines the relationship between feminism and other movements such as postmodernism, postcolonialism, power dynamics, mythology, and gender politics. Despite this, feminist research continues to regard itself as a component or offshoot of postmodernism [33]. An understanding of the orderly world of the feminist theory lies more appropriately in the territory of postmodern philosophy than it does in feminist theory. Postcolonialism and feminism, as critical discourses, have contributed to a better understanding of interrelations as well as their explanatory potential. This capability to embrace the complexity and unpredictability of global political and social life has increased dramatically in the last two decades as a result of the convergence of these two theoretical approaches. They are adamant in their support for subversion and change in the political, cultural, and social landscape; not just to bridge the gap between the center and the margins, but also to bring the knowledge of and from the margins to the center, as they have done throughout their lives. After the end of colonialism, feminism gains a conceptual toolkit that allows it to recognize multiple sites of oppression and to reject universal perspectives on both men's and women's experiences of gender discrimination. In feministic studies, power politics and oppression are intertwined. The ability to persuade someone else to do what you want them to do is known as power. As an exercise of power over people who define it as an ability or a capacity to act as a power to do something, it is done through deception and trickery. Essentially, Michel Foucault's widely cited theory of power assumes that it is a form of power-over, as he states, if we speak of the mechanisms of power it is only insofar as we think 
that certain person's exercise power over others [34]. In the context of power over relationships, and in the context of its actual exercise, power is understood and characterized as follows: It is not the case that the female existence and experience are unique in the way that mythological myths frequently portray them to be. It is an attempt to infuse a sense of humanity into narratives of female existence that have been rendered immobile by mythology and tradition in order to make them more relatable to modern women. Mythologies are sometimes hailed as the archetypal pictures and stories of humanity that will endure in perpetuity due to their universality and timeless quality. Feminism and gender dynamics are constantly intertwined in some way. A feminist ethos of critical engagement and responsiveness is intended to be embodied in gender studies, and it is intended to be attentive to evolving power relations while remaining open to the possibilities of feminist knowledge and practice. In this way, we can demonstrate that feministic research is interconnected with a wide range of other theoretical frameworks.

Chapter four of the thesis titled 'The Unmuted voice of Empress' thoroughly discusses the four selected novels The Fisher Queen's Dynasty by Kavita Kane, Aditi Banrjee's The Curse of Gandhari and Madhavi S Mahadeva's The Kaunteys and The Palace of Illusions by Chitra Banarjee Divakaruni. The novel The Fisher Queen's Dynasty revisits the Mahabharata from the perspective of Satyavati which is a piercing insightful look at the grand matriarch in which a woman set off the sequence of events. The Curse of Gandhari rescues Gandhari from being reduced to a mere symbol of her blindfold and it projects the wise reflections on womanhood. The Kaunteyas replaces the ideal mother figure with a fully three-dimensional woman, providing new insights into the epic. The Palace of Illusions revisits the great epic from the perspective of Draupadi and taken the male-centered story breathed new with female fragrance. All four empresses' of the epic are very bold and emerged as a powerful voice in the post-modern works. At the same time, the study also focuses on comparing these brilliant characters to the original Vyasa Bharata and shows how modern retellings reconstructed and become the voice of strangled mouths.

The fifth chapter is the concluding one which focuses on combining both western and Indian concepts of feminism and ascertains which is better for Indian ethnicity in the future. Mythology continues to be the part and parcel of the life of modern man even today. Women's study has donated completely by giving expression to the voices of ordinary women and incorporating their issues in the research agenda [35]. Our epic would remain unexplored and un-researched despite plenty of studies conducted on it. So, the thesis has the scope and is relevant to contemporary society. The information required for this exploratory research will be assembled from peer-reviewed journals, books, educational journals, and other online sources. The study will be incorporated into the different research papers published in peerreviewed journals and other online sources on female characters of Mahabharata. The planned and expected research will be accomplished within three years.

\section{SUMMARY OF FINDINGS BY VARIOUS JOURNAL ARTICLES :}

Table 2 summarizes the findings of several writers related to the selected topic by the peer reviewed journal articles.

Table 2: Summary of Findings

\begin{tabular}{|l|l|l|l|}
\hline $\begin{array}{l}\text { Sl. } \\
\text { No }\end{array}$ & \multicolumn{1}{|c|}{ Author } & Year & \multicolumn{1}{|c|}{ Findings } \\
\hline 1 & $\begin{array}{l}\text { Fitzgerald, J. L } \\
{[36]}\end{array}$ & 2003 & $\begin{array}{l}\text { This article exclusively focused on new interpretative ideas and } \\
\text { discovers how the text of Mahabharata bestowed a great contribution } \\
\text { to the time and place and the principles formed a significant legacy } \\
\text { since the centuries. }\end{array}$ \\
\hline 2 & $\begin{array}{l}\text { Dowd, Joseph. } \\
{[37]}\end{array}$ & 2011 & $\begin{array}{l}\text { The article analyses Krishna's tactics through western moral } \\
\text { philosophy by discovering the consequentialism, the ethical approach } \\
\text { of Krishna differs from the western ideas of ethics. }\end{array}$ \\
\hline 3 & $\begin{array}{l}\text { Pillai, Anila. } \\
{[38]}\end{array}$ & 2021 & $\begin{array}{l}\text { Seeking answers to the curiosity of the universe which is responsible } \\
\text { to the existence of myths. It establishes mythic tales as vital } \\
\text { ingredients for posterity. }\end{array}$ \\
\hline
\end{tabular}




\begin{tabular}{|c|c|c|c|}
\hline 4 & $\begin{array}{l}\text { Siwach, } \\
\text { Simran.[39] }\end{array}$ & 2021 & $\begin{array}{l}\text { The article re-imaging the Draupdi's view point in a dystopian } \\
\text { perspective by arguing the concept of dystopia is not bound to } \\
\text { scientific fiction but also applicable to other genres of the literature. }\end{array}$ \\
\hline 5 & $\begin{array}{l}\text { Jonathan, } \\
\text { Cheste.[40] }\end{array}$ & 2018 & $\begin{array}{l}\text { The paper focused on both Eastern and western spiritual and } \\
\text { psychological traditions and an integrated sense of oneness exists } \\
\text { ourselves. }\end{array}$ \\
\hline 6 & $\begin{array}{l}\text { Bailey, Greg. } \\
\text { [41] }\end{array}$ & 2007 & $\begin{array}{l}\text { The article tried to uphold the humanistic elements of the epic which } \\
\text { belonged not only India but entire world. Being the perennial source } \\
\text { of spiritual strength, it is a great source of study through the } \\
\text { breathtaking narration. }\end{array}$ \\
\hline 7 & $\begin{array}{l}\text { Majirana, } \\
\text { Jasvantbhai. } \\
\text { [42] }\end{array}$ & 2019 & $\begin{array}{l}\text { The historical and philosophical treatise of India written in the form } \\
\text { of the epic. The epic instills the bond of friendship, importance of } \\
\text { having the correct knowledge etc. }\end{array}$ \\
\hline 8 & $\begin{array}{l}\text { Agarwal, } \\
\text { Komal.[43] }\end{array}$ & 2017 & $\begin{array}{l}\text { In this article the character Draupadi is not read through the victim- } \\
\text { perpetrator lens but, as a learned scholar who is well-versed in the } \\
\text { debates of law and the codified system of ethics. }\end{array}$ \\
\hline 9 & $\begin{array}{l}\text { Gupta, Princi \& } \\
\text { Singh, Nisha. } \\
\text { [44] }\end{array}$ & 2019 & $\begin{array}{l}\text { Explores the strengths and weaknesses epic characters and discovers } \\
\text { the learning and managerial implications of these eminent characters } \\
\text { of Ramayan and Mahabharata. }\end{array}$ \\
\hline 10 & $\begin{array}{l}\text { Singh, Anita. } \\
{[45]}\end{array}$ & 2009 & $\begin{array}{l}\text { Indian feminist theatre is the source of empowerment of women by } \\
\text { giving opportunities to speak freely and brought real change in the } \\
\text { life of the women. }\end{array}$ \\
\hline 11 & $\begin{array}{l}\text { Mistra, } \\
\text { Deepanjali. } \\
\text { [46] }\end{array}$ & 2021 & $\begin{array}{l}\text { Information Technology brought drastic changes in the society. } \\
\text { Preservation of folklores and literature through digitization can } \\
\text { transcend originals and reach the information to a larger audience. } \\
\text { Digitization of the epic has lent a voice to the whole masses. }\end{array}$ \\
\hline 12 & $\begin{array}{l}\text { Singh, } \\
\text { Rajni.[47] }\end{array}$ & 2015 & $\begin{array}{l}\text { The paper analysis how the female self-created by the patriarchal } \\
\text { hegemony and sustained through tradition. It concentrates on the life } \\
\text { and story of Panchali depicted in Chitra Banarjee's novel The Palace } \\
\text { of Illusions. }\end{array}$ \\
\hline 13 & $\begin{array}{l}\text { Bhardwaj, } \\
\text { Lata. [48] }\end{array}$ & 2020 & $\begin{array}{l}\text { The article throws insightful light on the life of Draupadi of } \\
\text { Mahabharata and argued that she being a learned woman fails to live } \\
\text { completely and experiences sufferings throughout her life. }\end{array}$ \\
\hline 14 & $\begin{array}{l}\text { Sharma, } \\
\text { Bandana. [49] }\end{array}$ & 2020 & $\begin{array}{l}\text { The value of world's largest epic Mahabharata is not reduced even an } \\
\text { inch in the past } 5500 \text { years, instead it increases by the time passes and } \\
\text { the article focuses the epic's journey towards enlightenment. }\end{array}$ \\
\hline 15 & $\begin{array}{l}\text { Leavitt, John. } \\
\text { [50] }\end{array}$ & 1988 & $\begin{array}{l}\text { The } 5^{\text {th }} \text { century Sanskrit epic the Mahabharata is not retold in local } \\
\text { languages and recast in local settings. The paper traces the } \\
\text { happenings of the epic in Kumaon hills of Himalayas. }\end{array}$ \\
\hline 16. & $\begin{array}{l}\text { Vemsani, } \\
\text { Lavanya [51] }\end{array}$ & 2021 & $\begin{array}{l}\text { The chapter analysis how Sathyavati of Mahabharata emerges as a } \\
\text { captivating character to the reader. It is not mere a tale of war but } \\
\text { great source of strength and weakness of human being. }\end{array}$ \\
\hline 17. & $\begin{array}{l}\text { Rajpurohit, } \\
\text { Niranjan [52] }\end{array}$ & 2020 & $\begin{array}{l}\text { The lessons on effective leadership qualities from the ancient epic } \\
\text { from Shri Krishna which played a significant role in the victory of } \\
\text { Pandavas in the war and the poor leadership of king Dhritarashtra } \\
\text { caused the downfall. }\end{array}$ \\
\hline 18 & $\begin{array}{l}\text { Fitzgerald, } \\
\text { James. [53] }\end{array}$ & 1983 & $\begin{array}{l}\text { It assesses a critical viewpoint of India through Mahabharata, which } \\
\text { is the perfect narration of Indian culture and how it formed the origin } \\
\text { of nation's culture. }\end{array}$ \\
\hline 19 & $\begin{array}{l}\text { Nisha } \begin{array}{l}\text { \& } \\
\text { Phohat, Geeta. } \\
\text { [54] }\end{array} \\
\end{array}$ & 2017 & $\begin{array}{l}\text { The epic also a romance telling the story of heroic men and women } \\
\text { which include the code of life. It is also a philosophy of social and } \\
\text { ethical bonds and the embodiment of scripture. }\end{array}$ \\
\hline 20 & $\begin{array}{l}\text { Pal, } \\
\text { Pratapaditya. } \\
\text { [55] }\end{array}$ & 2016 & $\begin{array}{l}\text { The article explores the epic as the source of History of ancient India. } \\
\text { Present historiographical framing followed the prevailing British } \\
\text { school of history of the } 20^{\text {th }} \text { century. }\end{array}$ \\
\hline
\end{tabular}




\begin{tabular}{|c|c|c|c|}
\hline 21 & $\begin{array}{l}\text { Gupta, Princi. } \\
\text { [56] }\end{array}$ & 2019 & $\begin{array}{l}\text { The two great epics laid solid and enduring foundation of magnificent } \\
\text { edifice of Indian culture and civilization. The everlasting appeal of } \\
\text { these epics still influences the cultural life and behavioral pattern of } \\
\text { Indians. }\end{array}$ \\
\hline 22 & $\begin{array}{l}\text { Asthana, } \\
\text { Ashwini. [57] }\end{array}$ & 2019 & $\begin{array}{l}\text { People of India of the present day cherish in their heart the story of } \\
\text { Mahabharata. Archaeological facts of the text made us to realize the } \\
\text { truth. }\end{array}$ \\
\hline 23 & $\begin{array}{l}\text { Elizabeth, } \\
\text { Motswapong. } \\
\text { [58] }\end{array}$ & 2017 & $\begin{array}{l}\text { Draupadi is not presented as an unsung heroine but as a paragon of } \\
\text { gender and resistance on the injustice she faced. It explores her ability } \\
\text { to overcome all adversities in a venerable manner. }\end{array}$ \\
\hline 24 & $\begin{array}{l}\text { Vat, Kiran. } \\
{[59]}\end{array}$ & 2016 & $\begin{array}{l}\text { Without the wonderful character of Draupadi, there was no } \\
\text { Mahabharata at all. Being a princess and queen, her life was } \\
\text { sorrowful and disgraceful, full of thunder and lightning. }\end{array}$ \\
\hline 25 & $\begin{array}{l}\text { Maitra, Trina. } \\
{[60]}\end{array}$ & 2016 & $\begin{array}{l}\text { The article seeks to examine how notions of victimhood and agency } \\
\text { are playfully dealt with in the modern retellings of the Mahabharata. }\end{array}$ \\
\hline 26 & $\begin{array}{l}\text { Bose, } \\
\text { Arunabha. [61] }\end{array}$ & 2017 & $\begin{array}{l}\text { The article examines Mahasweta Devi's Kunti and Nishadin which is } \\
\text { a encounter between the Kshatriya queen and the untouchable } \\
\text { Nishadin. }\end{array}$ \\
\hline 27 & $\begin{array}{l}\text { Mandal, } \\
\text { Aparna. [62] }\end{array}$ & 2021 & $\begin{array}{l}\text { The Mahabharata is a multi-layered text can be interpreted from } \\
\text { myriad perspectives like burning of Khandava forest and the } \\
\text { disrobing of Draupadi unravels the deeper environmental issues. }\end{array}$ \\
\hline 28 & $\begin{array}{l}\text { Das, Saptorshi. } \\
\text { [63] }\end{array}$ & 2014 & $\begin{array}{l}\text { The article throws insightful look on one of the earliest recorded } \\
\text { protests against a male dominated world and society of Draupadi. Her } \\
\text { fight against injustice is one of the first act of feminism. }\end{array}$ \\
\hline 29 & $\begin{array}{l}\text { Singh, Kavita. } \\
\text { [64] }\end{array}$ & 2015 & $\begin{array}{l}\text { The article explores the feminist viewpoint of on iconic female } \\
\text { character of the epic, Draupadi. It depicts Draupadi in Chitra } \\
\text { Banerjee's The Palace of Illusions. }\end{array}$ \\
\hline 30 & $\begin{array}{l}\text { G, } \\
\text { Hampamma. } \\
\text { [65] }\end{array}$ & 2013 & $\begin{array}{l}\text { The epic is significant for the portrayal of its female characters as } \\
\text { strong, bold, fierce, assertive and independent. It explains how they } \\
\text { took independent decisions and faced its consequences. }\end{array}$ \\
\hline 31 & $\begin{array}{l}\text { Chandrasekhar, } \\
\text { B. S. [66] }\end{array}$ & 1983 & $\begin{array}{l}\text { The article analyses the Kannada novel Parva and it's an everlasting } \\
\text { impression on the social, historical and mythological preparations. }\end{array}$ \\
\hline 32 & $\begin{array}{l}\text { Dhand, } \\
\text { Arti.[67] }\end{array}$ & 2004 & $\begin{array}{l}\text { The article focuses on the unpacking of a key religious orientation of } \\
\text { the epic which explains the Karma yogic ideal of equanimity. }\end{array}$ \\
\hline 33 & $\begin{array}{l}\text { Hemphill, } \\
\text { Linda. [68] }\end{array}$ & 2012 & $\begin{array}{l}\text { The article explores the ethnographic focus on the women characters } \\
\text { of Mahabharata and the question of truth. }\end{array}$ \\
\hline 34 & $\begin{array}{l}\text { Chaudhary, } \\
\text { Ritu. [69] }\end{array}$ & 2020 & $\begin{array}{l}\text { It reads The Palace of Illusions as an attempt to reinterpret the gender } \\
\text { and psychological issues which testifies unawareness of double } \\
\text { marginality. }\end{array}$ \\
\hline 35 & $\begin{array}{l}\text { Black, Brian. } \\
{[70]}\end{array}$ & 2011 & $\begin{array}{l}\text { Readers of epic have long considered its female characters as most } \\
\text { fascinating and lively personalities through an extensive study of } \\
\text { female characters of the epic. }\end{array}$ \\
\hline 36 & $\begin{array}{l}\text { Jenkins, Katy. } \\
\text { [71] }\end{array}$ & 2019 & $\begin{array}{l}\text { In support of gender equality, it is an essential feminist values infuse } \\
\text { and underpin every aspect of research to create spaces and } \\
\text { opportunities to addressing the inequalities. }\end{array}$ \\
\hline 37 & $\begin{array}{l}\text { Ghosal, } \\
\text { Sarbani. [72] }\end{array}$ & 2005 & $\begin{array}{l}\text { The concept of feminism as a political ideology is closely related with } \\
\text { women's studies of the world. To focus of feminism in general should } \\
\text { see women in their own perspectives. }\end{array}$ \\
\hline 38 & $\begin{array}{l}\text { Pande, Rekha. } \\
\text { [73] }\end{array}$ & 2018 & $\begin{array}{l}\text { The historical background of the rise of feminism in India is entirely } \\
\text { different from the western concept of feminism. }\end{array}$ \\
\hline 39 & $\begin{array}{l}\text { Rai, Bharathi. } \\
\text { [74] }\end{array}$ & 2021 & $\begin{array}{l}\text { The article explores the last days of Karna of Mahabharata from the } \\
\text { viewpoint of Aristotle's concept of Hamartia. }\end{array}$ \\
\hline 40 & $\begin{array}{l}\text { Rai, Bharathi. } \\
{[75]}\end{array}$ & 2021 & $\begin{array}{l}\text { The article explores the character of Karna in the Mahabharata how } \\
\text { he was deprived and wronged from the social perspective. }\end{array}$ \\
\hline
\end{tabular}




\begin{tabular}{|c|c|c|c|}
\hline 41 & $\begin{array}{l}\text { Gabriel, } \\
\text { Bazimaziki } \\
\text { [76] }\end{array}$ & 2017 & $\begin{array}{l}\text { The paper assesses the depiction of human society through epic } \\
\text { literary genres. It depicts the epic as a perfect piece of literature. }\end{array}$ \\
\hline 42 & $\begin{array}{l}\text { Black, Brain. } \\
\text { [77] }\end{array}$ & 2013 & $\begin{array}{l}\text { The Article explores three dimensions of Draupadi's character. As a } \\
\text { divine figure, as an enraged and defenseless victim of sexual abuse } \\
\text { and as a female scholar. }\end{array}$ \\
\hline 43 & $\begin{array}{l}\text { Kumar, } \\
\text { Priyanka. [78] }\end{array}$ & 2016 & $\begin{array}{l}\text { The paper makes an attempt of the portrayal of the character of } \\
\text { Draupadi as strong, bold and assertive, having independent existence } \\
\text { in Divakaruni's The Palace of Illusions. }\end{array}$ \\
\hline 44 & $\begin{array}{l}\text { Bhardwaj, } \\
\text { Lata. [79] }\end{array}$ & 2020 & $\begin{array}{l}\text { This article examines the character of Draupadi and how a learned } \\
\text { woman fails to live fully in the light of the novel Yajnaseni. }\end{array}$ \\
\hline 45 & $\begin{array}{l}\text { Ambewadikar, } \\
\text { Jayashree. [80] }\end{array}$ & 2020 & $\begin{array}{l}\text { The article analyses how the following of culture, customs and } \\
\text { traditions by women evolved within the structure of power and } \\
\text { authority throughout the epic. }\end{array}$ \\
\hline 46 & $\begin{array}{l}\text { Daschaudhari, } \\
\text { Mohar. [81] }\end{array}$ & 2020 & $\begin{array}{l}\text { The article analyses the rewriting of the myth of Draupadi in Pratibha } \\
\text { Ray's Yainaseni and Chitra Banneriee's the Palace of Illusion. }\end{array}$ \\
\hline 47 & Izadi, G. [82] & 2017 & $\begin{array}{l}\text { The study focuses on the similarities dissimilarities between the } \\
\text { romances and the epic. It has compared and contrasted the epic and } \\
\text { the romance. }\end{array}$ \\
\hline 48 & $\begin{array}{ll}\text { C, } & \text { Akshara. } \\
{[83]} & \end{array}$ & 2019 & $\begin{array}{l}\text { The article explores how Mahasweta Devi uses a retelling of the } \\
\text { Mahabharata to emphasize the atrocities committed on the poor by } \\
\text { rich in her work 'Panchakanya'. }\end{array}$ \\
\hline 49 & $\begin{array}{l}\text { Pillai, Anila. } \\
\text { [84] }\end{array}$ & 2021 & $\begin{array}{l}\text { The paper establishes mythic tales as a vital ingredient for posterity } \\
\text { to look upon and validate that the rereading of mythic tales various } \\
\text { perspectives and dimensions to the legendary texts. }\end{array}$ \\
\hline 50 & Kane, P.V. [85] & 1966 & $\begin{array}{l}\text { The research paper compares and contrasts between two timeless } \\
\text { epics of India and highlights the importance of them in the modern } \\
\text { society. }\end{array}$ \\
\hline 51 & $\begin{array}{l}\text { Arlow, Jacob } \\
\text { A. [86] }\end{array}$ & 1961 & $\begin{array}{l}\text { The instinct of egoism among men expressed in mythology is } \\
\text { analyzed beautifully in this journal article. }\end{array}$ \\
\hline 52 & $\begin{array}{l}\text { Sharma, } \\
\text { Shreeja. [87] }\end{array}$ & 2020 & $\begin{array}{l}\text { The research paper segments the mythical narratives through the } \\
\text { attributes of mother-son association and mother-daughter association } \\
\text { to harness the contemporary aspects of a unified society. }\end{array}$ \\
\hline 53 & Luthra, R. [88] & 2014 & $\begin{array}{l}\text { The article argues that epics are the great sources of all queries on } \\
\text { women related matters. Man has the habit of going past in search of } \\
\text { answers and epics are the great sources for that concern. }\end{array}$ \\
\hline 54 & $\begin{array}{l}\text { Parmar, } \\
\text { Surabhi. [89] }\end{array}$ & 2019 & $\begin{array}{l}\text { The scholarly article throws light on the concept of dharma and } \\
\text { adharma in modern time based on the epic. It tries to answer some } \\
\text { untouched aspects of the epic. }\end{array}$ \\
\hline 55 & $\begin{array}{l}\text { Sullivan, } \\
\text { Bruce. [90] }\end{array}$ & 2006 & $\begin{array}{l}\text { The paper throws light on the most striking features in the } \\
\text { Mahabharata is the frequency with which self-willed death figures in } \\
\text { the narrative. }\end{array}$ \\
\hline 56 & $\begin{array}{l}\text { Sullivan, } \\
\text { Bruce. [91] }\end{array}$ & 2011 & $\begin{array}{l}\text { The article analyses on the end and endings of the epic that is different } \\
\text { time line used in the epic in a logical way. }\end{array}$ \\
\hline 57 & $\begin{array}{l}\text { Doshi, Hetal. } \\
{[92]}\end{array}$ & 2013 & $\begin{array}{l}\text { The paper attempts to portray the feminist history in India from a } \\
\text { common man's perspective. Equality can only be achieved by } \\
\text { broadening the psychosomatic horizons of both the genders. }\end{array}$ \\
\hline 58 & $\begin{array}{l}\text { Pusalker, A D. } \\
\text { [93] }\end{array}$ & 1956 & $\begin{array}{l}\text { The paper focuses on the studies in epics and puranas and evaluates } \\
\text { how it is relevant to men even today. }\end{array}$ \\
\hline 59 & $\begin{array}{l}\text { Roy, } \\
\text { Nishikanta \& } \\
\text { Sarkar, } \\
\text { Narayan. [94] }\end{array}$ & 2021 & $\begin{array}{l}\text { This article focuses on the socio-political ethics presented by Vidhur } \\
\text { in the great Indian epic Mahabharata. }\end{array}$ \\
\hline
\end{tabular}


60 Singh, Vikram. 2017 The article explores how the mythology displays an array of [95] divergent attitudes towards the characters and incidents.

\section{CONCLUSION :}

Mythology continues to be the part and parcel of the life of modern man even today. Women's study has gifted greatly by giving expression to the voices of ordinary women and incorporating their issues in the new knowledge. Epics are a very important part of our life. They can explain us the real meaning of life. They teach us how to live life. It has multi voices [96]. The Mahabharata is a maze of a variety of characters and themes. Women played an essential role in it. The role played by women in Mahabharata provides an interesting source of study providing deep insight into their strengths and weaknesses [97]. India is the land which worships all its aspects in the form of female [98]. There is ample of scope to explore in this area. The position of women in the Indian society since the ancient time has been commanding [99].Our epic would remain unexplored and un-researched despite plenty of studies conducted on it. So, there is much scope and it is relevant to contemporary society. Even though we are in the modern era of technology and advancement, gender discrimination is not yet eradicated. The portrayal of women in epics highlight the way their actions generate uncertainty around the transactions on which the patriarchy is based [100]. Women have proved their mettle in all fields, but exploitation and injustice against them are not yet uprooted. In this sense, the bold and beautiful retellings of the epic made their heroines magnificent harbinger of the change. They emerged as radiant and powerful voices that fight boldly towards their injustices and sufferings.

\section{REFERENCES :}

[1] Berk, Faith (2015). The Role of Mythology as a Cultural Identity and a Cultural Heritage. Journal of ScienceDirect, 23(27), 67-68.

Google Scholar $x^{\top}$

[2] Phelan, Kate (2021). Feminism as Epic Theory. British Journal of Political Science, 2(1), 1-14. Google Scholar $X^{\top}$

[3] Khan, A. K, \& Sen, M. (2021). Gender Equality: A Historical Perspective Based on Vedic Literatures. Review of International Geographical Education, 11(10), 598-601.

Google Scholar $\chi^{7}$

[4] Karthika, P. (2020). Myths and Markets: Marketability of the queer Mythical Tales by Devadutt Pattanaik. The Criterion: An International Journal in English, 11(6), 66-72.

Google Scholar $X^{\top}$

[5] Thaker, Keyur (2011). Management Control Insights from the Mahabharata. International Journal of Indian Culture and Business Management, 4(4), 377-389.

Google Scholar $X^{\top}$

[6] Banerjee, Chitra (2018). The Palace of Illusion. Picador, India. ISBN: 978-93-86215-96-3. 1-360. Google Scholar $\chi^{\top}$

[7] Gupta, Vipula (2020). The review of The Palace of Illusion by Chitra Banerjee Divakaruni. https://medium.com, retrieved on 12-06-2021

[8] Akshaya, J. (2020). "Myth and Feminine Identity in Chitra Banerjee Divakaruni' The Palace of Illusions." Journal of Xi' an University of Architecture and Technology, 12(5), 3475-3479. Google Scholar ${ }^{\top}$

[9] Banerjee, Aditi (2019). The Curse of Gandhari. Bloomsbury India. ISBN: 978-93-88002-00-4. 1317.

[10] Kaipa, Prasad. (2014). Making Wise Decisions: Leadership Lessons from Mahabharata. Journal of Management Development, 33(8). 836-846.

Google Scholar $x^{\top}$

[11] Datta, Sravasti (2019). Decoding Gabdhari, the Queen of Iron Will. https://www.thehindu.com, retrieved on 14-06-2021. 
[12] Warden, Harsha (2019). The Curse of Gandhari by Aditi Banerjee-A Review. https://www.indictoday.com. Retrieved on 15-06-2021.

[13] Tharu, Rajkumar (2021). The Pacifistic Reading of the Mahabharata. International Journal of English Language, Literature and Translation Studies, 8(1), 180-187.

Google Scholar $\chi^{7}$

[14] Kane Kavita (2017). The Fisher Queen's Dynasty. Westland Publication ltd, New Delhi. ISBN: 978-93-86850-17-1. pp 1-316.

Google Scholar $\chi^{7}$

[15] Ravi, Runoo (2019). Power Struggle and Political Games in the Mahabharata: A Brief Study through Select Characters. The Criterion: An International Journal in English, 10(1), 36-47.

Google Scholar ${ }^{\top}$

[16] Mahadevan, Madhavi (2016). The Kaunteyas. Tranquebar Press, New Delhi. ISBN: 978-9386224-18-7. Pp 1-389.

[17] Gosh, Baisakhi (2021)). Anecdote of Woman Study and Woman-hood in Mahabharata: A Critical Study. Journal of Xi'an of Architecture and Technology, 13(5), 520-525.

Google Scholar $X^{\top}$

[18] Singh, Kudeep (2020). Retelling of Uruvi in the Mahabharata: Kavita Kane's Karna's Wife: The Outcast's Queen. Journal of Interdisciplinary Cycle Research, 12(8), 764-768.

Google Scholar X

[19] Priya, Rashmi (2020). Women Characters in Kavita Kane's Karna's Wife: An outcast's Queen: A Feminist Perspective. The Refereed and Peer Review International Journal, 7(89), 60-63.

Google Scholar $X^{\top}$

[20] Pattanaik, Devdutta (2010). Jaya Mahabharata. Penguin Random House India. ISBN: 9780143104254. Pp 1-345.

Google Scholar $\nearrow^{7}$

[21] Lutgendrof, Philip (2012). Epic Nation: Reimaging the Mahabharata in the Age of the Empire. Journal of Contemporary Asia, 42(2), 338-340.

Google Scholar $\chi^{\top}$

[22] Jamison, Stephanie (2008). Gender and Narrative in Mahabharata. Journal of American Oriental, 128(02), 392-395.

Google Scholar X

[23] Simon, Brodbeck \& Brian Black (2007). Gender and Narrative in the Mahabharata. Routledge Hindu Studies Series, London, pp 97-165.

Google Scholar $\chi^{7}$

[24] Berk, Faith (2016). The Role of Mythology as a Cultural Identity and a Cultural Heritage. The Journal of Aesthetics and Art Criticism, 48(4), 395-408.

Google Scholar X'

[25] Izadi Gholam (2017). Heroic Legends and Epic. Journal of History Culture and Art Research, 6(1), 602-616.

Google Scholar $x^{\top}$

[26] Dixon, K, Violet (2011). Western Feminism in a Global Perspective. INQUIRIES Journal, 3(2), 88-99.

Google Scholar $\not^{7}$

[27] Kaur, Rajpal (2016). Feminism: Introduction and Aims. Imperial Journal of Interdisciplinary Research (IJIR). 2(6), 64-72.

Google Scholar X

[28] Chaudhari, Maitrayee (2012). Feminism in India: The Tale and its Telling." Journal of Dans Revue Tiers Monde, 12(1), 19-30. 
Google Scholar $\not 7$

[29] Parashar, Swati (2017). Feminism and Postcolonialism: (En) gendering Encounters. Journal of Postcolonial Studies, 19(4), 36-48.

Google Scholar $X^{\top}$

[30] Roseneil, Sasha (1999). Postmodern Feminist Politics. The European Journal of Women's studies, 6(2),161-182.

Google Scholar $\not 7$

[31] Narain, Seema (2014). Gender in International Relations: Feminist Perspectives of J. Ann Tickner. Indian Journal of Gender Studies, 21(2), 179-197.

Google Scholar $X^{\top}$

[32] Brunell, Laura \& Burkett Elinor (2019). Feminism. Encyclopedia Britannica. https://www.britannica.com, retrieved on 18-06-2021.

[33] Mambrol, Nasrullah (2018). Postmodernism and Feminism. Literary Theory and Criticism. https://literariness.org, retrieved on 20-06-2021.

[34] Foucault, Michel (1980). Power/Knowledge: Selected Interviews and Other Writings 1972-1977. Ed. Colin Gorden, London: Harvest Press. pp 95-99.

Google Scholar $\chi^{7}$

[35] Jekins, Katy \& Sweetman, Caroline (2019). Introduction: Feminist Values in Research. Journal of Gender and Development, 27(3), 415-425.

Google Scholar X

[36] Fitzgerald, J. L. (2003). The Many Voices of the Mahabharata. Journal of the American Oriental Society, 123(4), 803-818.

Google Scholar ${ }^{\top}$

[37] Dowd, Joseph. (2011). Maximizing Dharma: Krishna's Consequentialism in the Mahabharata. Praxis, 3(01), 33-50.

Google Scholar $\chi^{\top}$

[38] Pillai, Anila (2021). Myth Theory: A Study towards Mythic Tale \& It's Reach in Today's Life. International Journal of English Language, Literature in Humanities, 9(9), 8-21.

Google Scholar $x^{\nearrow}$

[39] Yadav, Bir Singh (2013). Building and Breaking Illusions in Patriarchal Universe: An Explorative Insight into Chitra Banerjee Divakaruni's the Palace of Illusions. Labyinth: An International Refereed Journal of Postmodern Studies, 4(1), 103-112.

Google Scholar $x^{\top}$

[40] Lakshmi, K. (2011). The Implications of Sthitaprajnatva in the Context of Self and Psychological Well-being: A Character Study from the Mahabharata. Indian Journal of Health and Wellbeing Thought, 2(5), 960-963.

Google Scholar $x^{7}$

[41] Bailey, Greg (2007). Humanistic Elements in the Mahabharata. Journal of South Asian Studies, 16(1), 1-23.

Google Scholar $x^{\top}$

[42] Majirana, Jasvantbhai (2019). An Analytical Study of Mahabharata as an Epic. Journal of Emerging Technologies and Innovative Research, 6(04), 8-11.

Google Scholar $X$

[43] Agarwal, Komal (2017). Draupadi Jeopardizing Jurisprudence: A Critical Analysis of Dharma as Law in the Light of Draupadi's Questions in the Sabha. Rupkatha Journal on Interdisciplinary Studies in Humanities, 9(01), 133-139.

Google Scholar X 
[44] Gupta, Princi \& Singh, Nisha (2019). A Comparative Study of the Strategies and Lessons of Two Great Indian Epics: Mahabharata and Ramayana. International Journal of Research in Engineering IT and Social Sciences, 9(2), 310-316.

Google Scholar X

[45] Singh, Anita (2009). Aesthetics of Indian Feminist Theatre. Rupkatha Journal of Interdisciplinary Studies in Humanities, 11(02), 150-170.

Google Scholar $\chi^{\top}$

[46] Mistra, D. (2021). Digitization of Texts: An Analysis with References Indian Epic Mahabharata. SPAST Abstracts, 1(01), 115-116.

Google Scholar $X^{\top}$

[47] Banerjee, S \& Singh, Rajni (2015). Becoming Krishna: Panchali's Quest in Chitra Banerjee Divakaruni's the Palace of Illusions". Rupkatha Journal on Interdisciplinary Studies in Humanities, 7(03), 186-195.

Google Scholar $x^{7}$

[48] Bhardwaj, Lata. (2020). Feminism in Mahabharata: The Unheard Voice of Draupadi. International Journal of Research and Analytical Reviews (IJRAR), 7(01), 441-445.

Google Scholar $\chi^{\top}$

[49] Sharma, Bandana (2017). The Mahabharata: A Journey to Enlightenment. The Criterion: An International Journal in English, 8(6), 100-118.

Google Scholar $\chi^{\top}$

[50] Leavitt, John (1988). A Mahabharata Story from the Kumaon Hills. HIMALAYA, 8(02), 1-13. Google Scholar $\chi^{\nearrow}$

[51] Vemsani, Lavanya (2021). Satyavati: Ferrier of the Family. Journal of Feminine Journey's of the Mahabharata, 2(1), 23-42.

Google Scholar ${ }^{7}$

[52] Rajpurohit, Niranjan (2020). Leadership Lessons from the Ancient Indian Epic of Mahabharata. PalArch's Journal of Archeology of Egypt/Egyptology, 17(6), 426-431.

Google Scholar $X^{\top}$

[53] Fitzgerald, James (1983). The Great Epic of India as Religious Rhetoric: A Fresh Look at the Mahabharata. Journal of the American Academy of Religion, 51(4), 611-630.

Google Scholar X

[54] Brodbeck, Simon (2010). Stri: Women in Epic Mahabharata. Indo-Iranian Journal, 53(01), 89-94. Google Scholar $x^{\top}$

[55] Pal, Pratapaditya (2016). A Mahabharata of a History of Ancient India. Sage Journals of Indian Historical Review, 43(02), 316-325.

Google Scholar 7

[56] Gupta, Princi (2019). A Comparative Study of the Strategies and Lessons of Two Great Indian Epics: Ramayana and Mahabharata. International Journal of Research in Engineering, IT and Social Sciences, 9(special Issue), 310-318.

Google Scholar $x^{\top}$

[57] Asthana, Ashwini (2019), Investigating Mahabharata through Inscriptions. Research Journal of Humanities and Social Science, 10(04), 1113-1119.

Google Scholar 7

[58] Elizabeth, Motswapong (2017). Understanding Draupadi as a Paragon of Gender and Resistance. Stellenbosch Theological Journal (STJ), 3(03), 477-492.

Google Scholar $\chi^{\top}$

[59] Vat, Kranti (2016). Status and Sufferings in the Life of Draupadi in Mahabharata. International Journal of Research in economics and Social Sciences, 6(12), 34-43. 
Google Scholar 7

[60] Maitra, Trina (2016). Gender-Bending in the Mahabharata: Questioning Fixed Notions of Identity. Ashvamegh, 6(17), 35-48.

Google Scholar X'

[61] Bose, Arunabha (2017). Motherhood and Mourning in Kunti and the Nishadin. Bharatiya Praja, An Interdisciplinary Journal of Indian Studies, 2(02), 1-8.

Google Scholar $\chi^{\top}$

[62] Mandal, Aparna (2021). The Environmental Philosophy in the Mahabharata: The Defilement of Khandavana and Draupadi. International Journal of Research in Humanities, Arts and Literature (IJRHAL), 9(6), 65-72.

Google Scholar X

[63] Das, Saptorshi (2014). Vyasa's Draupadi: A Feminist Representation. International Journal of Gender and Women's Studies, 2(02), 223-231.

Google Scholar $\chi^{\top}$

[64] Singh, Kavita (2015). Draupadi: A Compassionate Protagonist. International Journal of English Literature and Linguistics, 2(01), 103-105.

Google Scholar $\chi^{7}$

[65] Hampamma, G. (2013). Women of Mahabharata: Perspective of Shashi Despande. International Journal of Physics and Social Sciences), 3(9), 27-35.

Google Scholar $\not$ '

[66] Chandrasekhar, B. S. (1983). Mahabharata in the Modern Idiom. Indian Literature, 26(3), 92-95. Google Scholar ${ }^{\top}$

[67] Dhand, Arti (2004). The Subversive Nature of Virtue in the Mahabharata: A Tale about Women, Smelly Asetics and God. Journal of the American Academy of Religion, 72(01), 33-58.

Google Scholar $x^{\top}$

[68] Hemphill, Linda (2012). Women of the Mahabharata: The Question of Truth. Journal of South Asian Studies. 35(03), 765-766.

Google Scholar $\chi^{\top}$

[69] Chaudhary, Ritu (2020). Identifying Gender Dichotomy and Obscure Self in Chitra Divakaruni's Novel the Palace of Illusions. European Journal of Molecular and Clinical Medicine, 7(03), 1-7. Google Scholar $X^{\top}$

[70] Black, Brian (2011). Stri: Women in the Mahabharata. Journal of Asian Studies, 70(01), 282-284. Google Scholar $\not$

[71] Jenkins, Katy (2019). "Introduction: Feminist Values in Research". Journal of Gender and Development, 27(03), 415-425.

Google Scholar $X^{7}$

[72] Ghosal, Sarbani (2005). Major Trends of Feminism in India. The Indian Journal of Political Sciences, 66(04), 793-812.

Google Scholar $X^{\top}$

[73] Pande, Rekha (2018). The History of Feminism and Doing Gender in India. Revista Estudos Feminists, 26(3), 1-17.

Google Scholar 7

[74] Rai, Bharathi (2021). An Exploration of Karna's Last Days through the Prism of Aristotle's Hamartia. International Journal of Management, Technology and Social Sciences (IJMTS), 6(2), 133-146.

Google Scholar $x^{7}$ 
[75] Rai, Bharathi (2021). Re-inventing Karna of the Mahabharata with a Renewed Perspectives- A Review of Literature. International Journal of Management, Technology and Social Sciences (IJMTS), 6(2), 75-87.

Google Scholar $\triangle 7$

[76] Gabriel, Bazimaziki (2017). Depiction of Human Society Through Epic Literary Genres. International Journal of English and Literature, 8(5), 63-73.

Google Scholar $\nearrow$

[77] Black, Brain (2013). Draupadi in the Mahabharata. Religion Compass, 7(5), 169-178. Google Scholar $\nearrow$

[78] Kumar, Priyanka (2016). Chitra Banerjee Divakaruni’s The Palace of Illusions: Revisiting the Epic through the Eyes of an Extraordinary Woman. Research Journal of English Language and Literature, 4(1), 432-434.

Google Scholar $\chi^{\nearrow}$

[79] Bhardwaj, Lata (2020). Feminism in Mahabharata: The Unheard Voice of Draupadi. International Journal of Research and Analytical Reviews, 7(1), 441-445.

Google Scholar $\nearrow$

[80] Ambewadikar, Jayashree. (2000). Women, Selfhood and Social Institutions: A Study of Epic of Mahabharata. Serials Journals, 97(26), 495-506.

Google Scholar $\nearrow$

[81] Daschaudari, Mohar (2020). Re-Writing the Myth of Draupadi in Pratibha Ray's Yajnaseni and Chitra Bannerjee's The Palace of Illusion. Athens Journal of Philology, 7(3), 171-188.

Google Scholar $\nearrow$

[82] Izadi, G. (2017). Heroic Legends and Epic. Journal of History Culture and Art Research, 6(1), 602-616.

Google Scholar $x^{7}$

[83] Akshara, C. (2019). The Gendered Retelling of the Epic: A study of Mahasweta Devi's Panchakanya. An International Refereed-cum-Peer-Reviewed Research Journal of English Literature and Language, 11(12), 63-71.

Google Scholar $\nearrow$

[84] Pillai, Anila (2021). Myth Theory: A Study towards Mythic Tale and It's Reach in Today's Life. International Journal of English Language, Literature in Humanities, 9(9), 8-21.

Google Scholar $X^{\nearrow}$

[85] Kane, P. V. (1966). The Two Epics. Annals of the Bhandarkar Oriental Research Institutes, 47(4), 11-58.

Google Scholar $\nearrow$

[86] Arlow, Jacob A. (1961). Ego Psychology and the Study of Mythology. Journal of the American Psychoanalytic Association, 9(3), 371-393.

Google Scholar $\nearrow$

[87] Sharma, Shreeja (2020). The Mother in Myth: Narratives of Trauma in Collective Memory. Smart Moves Journal IJELLH, 8(10), 194-201.

Google Scholar $\chi$

[88] Luthra, R. (2014). Clearing Sacred Ground: Women-Centered Interpretations of the Indian Epics. Feminist Formations, 26(2), 135-161.

Google Scholar $Х$

[89] Parmar, Surabhi (2019). Dharmakshetra: An Epic Series Interpreting Dharma- Adharma after the Kurukshetra. International Journal of English Language, Literature in Humanities, 7(1), 18231832.

Google Scholar $\chi$ 
[90] Sullivan, Bruce (2006). The Ideology of Self-willed Death in the Epic Mahabharata. Journal of Vaishnava Studies, 14(2), 61-79.

Google Scholar $X^{\top}$

[91] Sullivan, Bruce (2011). The Mahabharata: Perspectives on Its Ends and Endings. International Journal of Hindu Studies, 15(1), 1-7.

Google Scholar $X$

[92] Doshi, Hetal (2013). Feminist Reading of Indian Epics: Exploring Sita and Draupadi through the Current Perception. The IUP Journal of English Studies, 8(4), 81-85.

Google Scholar X'

[93] Pusalker, A D. (1958). Studies in the Epics and Puranas of India. Annals of the Bhandarkar Oriental Research Institutes, 37(4), 348-350.

Google Scholar $x^{\top}$

[94] Roy, Nishikanta \& Sarkar Narayan (2021). The Present Social Relevance of Vidhur's Principles Depicted in The Mahabharata. International Journal of Advanced Multidisciplinary Scientific Research, 4(10), 1-10.

Google Scholar $\nearrow^{7}$

[95] Singh, Vikram (2017). Modern Retellings of Indian Myths: A Study of Rehashing Mythology through Popular Fictions. International Journal of Research in Humanities, Arts and Literature, 5(10), 171-176.

Google Scholar $x^{7}$

[96] Fitzgerald, James \& Hiltebeitel, Alf (2003). The Many Voices of the Mahabharata. Journal of the American Oriental Society, 123(4), 803-818.

Google Scholar ${ }^{\top}$

[97] Wadley, Susan (1977). Women and the Hindu Traditions. Signs: Journal of Women in Culture and Society, 3(1), 113-125.

Google Scholar $\nearrow^{\top}$

[98] Sahu, B. P. (2017). The State in Early India: An Overview. Proceedings of the Indian History Congress, 55(94), 88-98.

Google Scholar $x^{7}$

[99] Sutherland, Sally (1989). Sita and Draupadi: Aggressive Behavior and Female Role-Models in the Sanskrit Epics. Journal of the American Oriental Society, 109(1), 63-79.

Google Scholar $X^{\top}$

[100] Laity, K. A. (2010). Women and Medieval Epic: Gender, Genre and the Limits of Epic Masculinity. The Journal of Medieval Religious Culture, 36(2), 256-258.

Google Scholar $\not$

$* * * * * * *$ 